\title{
PENGEMBANGAN SISTEM PEMBELAJARAN BERBANTUAN WEB DENGAN MENGAPLIKASIKAN STRATEGI SELF-REGULATED LEARNING
}

\section{(DEVELOPMENT OF WEB FACILITATED LEARNING BY APPLYING SELF-REGULATED LEARNING STRATEGY)}

\author{
Dinda Aya Sofia \\ Program Studi Teknologi Pembelajaran, \\ Pascasarjana Universitas Negeri Malang \\ E-mail:dindaayasofia@yahoo.com
}

\begin{abstract}
Abstrak: Pemanfaatan internet di dunia pendidikan bukan lagi menjadi hal yang baru. Program elearning menjadi salah satu metode pilihan dalam pendidikan saat ini. Dengan konsep belajar ini, pebelajar dapat belajar dengan tak terbatas waktu dan tempat. Tetapi jika dilihat dari keefektifaannya, tidak banyak lembaga pendidikan menjalankannya dengan efektif. Tujuan dari penelitian pengembangan ini adalah untuk menghasilkan sistem pembelajaran berbantuan web yang di dalamnya menerapkan strategi Self-regulated learning. Selain itu pengembangan ini juga bertujuan untuk menyediakan sebuah lingkungan belajar yang baru bagi pebelajar untuk berkesempatan melakukan interaksi dan diskusi tanpa dibatasi ruang dan waktu. Adapun Model pengembangan yang digunakan adalah model pengembangan Lee\&Owens. Produk pengembangan ini divalidasikan kepada Ahli Materi, Ahli Media dan Ahli Pembelajaran serta diuji-cobakan kepada mahasiswa Pascasarjana Program Studi Teknologi Pembelajaran Universitas Negeri Malang angkatan 2014 yang berjumlah 24 orang. Dari hasil validasi dan uji coba tersebut diperoleh kesimpulan bahwa pengembangan pembelajaran yang dikembangkan dinyatakan valid sehingga layak digunakan. Berdasarkan hasil pengembangan, maka diharapkan adanya penelitianpenelitian lain yang sejenis. Misalnya penelitian untuk mengetahui pengaruh dan efektivitas pembelajaran berbantuan web.
\end{abstract}

Kata kunci: Pengembangan Pembelajaran, Web, Strategi Self-Regulated Learning.

\begin{abstract}
Internet use in education system is no longer a new trends. E-learning program is one of the choice method in education today. The purpose of this development research is to produce a web-assisted learning systems by using Self-regulated learning strategy. In addition, the development also aims to provide a new learning environment for learners to have the opportunity to interact and discuss without being limited space and time.The development model used was Lee \& Owens model. Design Expert and tested to 24 postgraduate students of Instructional Technology, State University of Malang years 2014. From the validation and the trial results concluded that the development of instructional developed was valid so that can be used. Based on the results of the development, it is expected that there are another similar studies. For example a study to determine the effect and effectiveness of web-facilitated learning.
\end{abstract}

Keyword: Instructional Development, Web, Self-Regulated Learning Strategy. 
Pemanfaatan internet di dunia pendidikan bukan lagi menjadi hal yang baru. Program e-learning menjadi salah satu metode pilihan dalam pendidikan saat ini. Dengan konsep belajar ini, pe-belajar dapat belajar dengan tak terbatas waktu dan tempat. Dimungkinkan pula para pebelajar dapat belajar sesuai kecepatannya masing-masing, mengula-ngi mempelajari materi setiap saat ketika mereka butuh serta menyediakan materi audio-visual (Peterson, 2004).

Tetapi jika dilihat dari keefektifannya, tidak banyak lembaga pendidi-kan menjalankannya dengan efektif. Sa-lah satu faktor penyebabnya adalah kurangnya partisipasi para pengajar dan pebelajar dalam menggunakan e-lear-ning yang mungkin dikarenakan oleh tidak menariknya konten atau fasilitas yang disajikan.

Selain kemudahan dan kebeba-san ruang dan kelompok dalam belajar yang dimiliki e-learning, di sisi lain terdapat beberapa kelemahan yang ada. Atas dasar hukum kebebasan dalam konsep e-learning, pebelajar justru seringkali dibebaskan dan dibiarkan begitu saja. Ketiadaan kontrol belajar dari tutor menjadikan pebelajar kadang-kadang hanya belajar sebatas ala kadar-nya saja.

Padahal sesuai pendekatan stu-dents centered learning, pebelajar ditun-tut untuk lebih berpartisipasi dalam tiap aktivitas pembelajaran. Proses belajar akan terjadi apabila pebelajar secara aktif terlibat atau melakukan kegiatan belajar. Keaktifan disini bukan hanya bermakna kehadiran di dalam "kelas" semata, melainkan berupa aktivitasaktivitas belajar seperti mengikuti penjelasan pengajar, mencatat hal-hal penting, bertanya, berdiskusi dengan teman, mengerjakan tugas baik individu maupun kelompok, mengkritisi tugas-tugas dan kegiatan-kegiatan, merang-kum materi dan sebagainya.

Dengan mengembangkan e-learning yang terintegrasi dengan social network diharapkan mampu menarik minat pebelajar untuk menggunakan e-learning tanpa meninggalkan aktifitas di social network. Konsep Learning Social Network merupakan sebuah pembela-jaran secara online dimana pebelajar ak-an mencari, menganalisis dan membagi kembali material pembelajaran yang dimilikinya.

Learning Social Network (LSN) adalah salah satu Social Network Sites (SNS) yang dirancang untuk memfa-silitasi pembelajaran. Dengan memanfa-atkan LSN, pengguna dapat dimudahkan dalam hal instalasi tanpa harus mem-bangun web dari awal. Telah terdapat halaman web yang sudah tersedia leng-kap dengan fitur-fiturnya yang edukatif.

Konsep Learning Social Net-work dapat dilakukan dengan meman-faatkan salah satu aplikasi berbasis web yaitu Edmodo. Adapun alasan pemilihan aplikasi Edmodo ini antara lain (1) edmodo merupakan salah satu jenis Learning Social Network (LSN) yaitu jejaring sosial berbasis edukasi, (2) aktivitas-aktivitas pembelajaran mulai dari penugasan sampai evaluasi seperti halnya dalam kelas dapat dilakukan pula melalui Edmodo dan (3) pebelajar telah familiar dengan Edmodo sehingga mu-dah dalam pengoperasiannya.

Adapun setting penelitian dan pengembangan dilakukan di Program Studi Teknologi Pembelajaran Pasca-sarjana Universitas Negeri Malang. Pe-nelitian berfokus pada Matakuliah Eva-luasi Program Pembelajaran. Mataku-liah ini mempelajari strategi/ teknik dan model-model evaluasi dan pengukuran program dan praktik pembelajaran yang diperlukan dalam rangka menentukan tingkat keberhasilan dan sebagai umpan balik untuk penyusunan program pem-belajaran.

Penelitian ini dilakukan dengan tujuan untuk menghasilkan suatu sistem pembelajaran berbantuan web yang di dalamnya menerapkan strategi Self-regulated learning. Penelitian ini diharap-kan dapat memberikan sumbangan un-tuk meningkatkan prestasi belajar pebe-lajar melalui peningkatan kemampuan belajar mereka yang lebih terarah dan terkontrol. Penelitian ini diharapkan ju-ga dapat memberikan sumbangan pen-getahuan di bidang pendidikan, terutama pada bidang 
pendidikan yang mengem-bangkan konsep selfregulated learning melalui pemanfaatan software aplikasi berbasis web.

\section{METODE}

Penelitian ini merupakan sebuah penelitian dan pengembangan (Research and Development). Model pengemba-ngan yang digunakan adalah model pengembangan Lee\&Owens. Secara garis besar Lee\&Owens (2004) men-jelaskan proses pengembangan yang memiiki lima tahapan, yaitu (1) Analisis (Analysis), (2) Perancangan (Design), (3) Pengembangan (Development), Penerapan (Implementation) dan (5) Evaluasi (Evalu-ation).

Pada bagian awal pengem-bangan model Lee\&Owens yaitu tahap analisis memisahkan fase analisis menjadi dua bagian menjadi analisis kebutuhan (need assessment) dan analisis awal-akhir (front end analysis). Need assessment adalah cara sistematik untuk menentukan kesenjangan antara keadaan nyata saat ini dengan keadaan yang dinginkan. Need assessment juga didefinisikan sebagai proses sistematik untuk menentukan tujuan, mengidenti-fikan perbedaan antara kondisi nyata dengan kondisi yang dinginkan, dan menen-tukan prioritas tindakan yang akan dilakukan. (Lee, William W. \& Owens, Diana L., 2004). Sedangkan Front-End Analysis adalah teknik pen-gumpulan data yang digunakan untuk menjembatani kesenjangan yang ada antara kenyataan dan harapan untuk menyelesaikan masalah-masalah yang ada. Terdapat sepuluh tahapan dalam front-end analysis yaitu 1) Analisis peserta, 2) Analisis teknologi, 3) Analisis situasi, 4) Analisis tugas, 5) Analisis Isu 6) Analisis kejadian penting, 7) Analisis tujuan, 8) Analsis Media, 9) Analisis Data yang ada, dan 10) Analisis Biaya.

Tahapan kedua adalah desain yaitu fase perencanaan dalam sebuah proyek multimedia. Tahapan ini meru-pakan bagian yang sangat penting untuk meraih kesuksesan pengembangan. Ke-giatan yang dilakukan adalah menyu-sun jadwal (Schedule), menentukan Pro-ject Team, spesifikasi media dan struktur material pembelajaran serta konfigurasi kontrol.

Tahapan ketiga adalah pengembangan, tahap ini merupakan realisasi dari rancangan (blue-print) yang telah dibuat sebelumnya. Artinya, apabila dalam tahap desain diperlukan suatu software untuk pengembangannya, ma-ka pada tahap inilah konten dalam soft-ware tersebut dikembangkan.

Tahapan keempat adalah implementasi yang merupakan tahap untuk menerapkan sistem yang sedang dikembangkan. Jadi pada tahap ini semua komponen yang dikembangkan diatur sedemikian rupa sesuai peran dan fungsinya agar program dapat berjalan sesuai harapan pengembang. Pada tahap ini produk telah direvisi dan dinyatakan layak untuk diujicobakan kepada peng-gunanya.

Tahapan kelima adalah evaluasi yang juga merupakan tahap akhir dalam model pengembangan Lee\&Owens. Me-nurut Lee\&Owens, tahap evaluasi dapat dilakukan dengan dua tahapan yaitu evaluasi formatif dan evaluasi sumatif. Pada pengembangan ini, kegiatan hanya dilakukan sampai tahap evaluasi forma-tif dengan tujuan untuk mengetahui mutu dan kualitas hasil pengembangan.

Uji coba produk dalam pengembangan ini dimaksudkan untuk menge-tahui tingkat keefektifan, efisiensi dan daya tarik hasil pengembangan. Hasil pengembangan divalidasikan kepada ahli materi, ahli media dan ahli pembe-lajaran untuk ditanggapi dan dilakukan revisi. Hasil pengembangan yang telah direvisi baru diujicobakan kepada maha-siswa secara perseorangan, kelompok kecil dan menyeluruh (lapangan). Ada-pun Jenis data dalam pengembangan ini berupa data kualitatif dan data kuan-titatif. Metode pengumpulan data yang digunakan dalam penelitian pengem-bangan kuesioner, observasi dan studi doku-menter. Teknik analisis data yang digunakan dalam pengembangan ini adalah menggunakan analisis statistik deskriptif dan analisis deskriptif kua-litatif. 


\section{HASIL}

Hasil pengembangan ini menghasilkan sebuah produk berupa pembelajaran dalam konsep Online Learning Environment dengan memanfaatkan sebuah aplikasi berbasis web yang didalamnya menerapkan strategi Self-regulated learning. Adapun pengem-bangan ini memanfaatkan salah satu Learning Social Network (LSN) yaitu Edmodo.

Produk pengembangan ini divalidasikan kepada Ahli Materi, Ahli Media dan Ahli Pembelajaran serta diujicobakan kepada mahasiswa Pasca-sarjana Program Studi Teknologi Pem-belajaran Universitas Negeri Malang angkatan 2014 yang berjumlah 24 orang. Dari hasil validasi dan uji coba tersebut diperoleh kesimpulan bahwa pengem-bangan pembelajaran yang dikembang-kan dinyatakan valid sehingga layak digunakan. Hal ini dibuktikan dengan hasil uji hasil uji ahli materi mencapai tingkat kevalidan 93,68\%; ahli media mencapai tingkat kevalidan $74 \%$; ahli pembelajaran mencapai tingkat keva-lidan 85,33\%; hasil uji coba kepada mahasiswa secara perseorangan menca-pai tingkat kevalidan 80\%; hasil uji coba kelompok kecil mencapai tingkat kevali-dan $81,19 \%$, dan hasil uji coba lapangan mencapai tingkat kevalidan $82,95 \%$.

\section{PEMBAHASAN}

Pengembangan pembelajaran berbantuan web dengan mengapli-kasikan strategi self-regulated learning pada mata Kuliah Evaluasi Progam dan Pelaksanaan Pembelajaran dikembang-kan setelah melewati tahapan-tahapan validasi dan uji coba. Berdasarkan ta-hapan tersebut dilakukan beberapa revisi berdasarkan saran dan tanggapan dari validator dan mahasiswa untuk mem-perbaiki kekurangan dan meningkatkan kualitas pengem-bangan.

Untuk dapat memfasilitasi pro-ses belajar mahasiswa yang menerapkan prinsipprinsip pengembangan self-regulated learning (SRL), cara yang digunakan adalah dengan memper-banyak tugas dan latihan.
Dalam hal ini, dosen menugaskan mahasiswa untuk mencatat semua kegiatan belajar baik terstruktur maupun mandiri dalam rangka penguasaan materi pembelajaran dan ditulis dalam resume perkulia-hannya. Dengan resume tersebut, baik dosen maupun mahasiswa dapat ber-sama-sama memonitor, mengontrol pro-ses dan hasil belajar yang dilakukan. Untuk itu, penting dilakukan tidak hanya pemberian tugas, tetapi harus disertakan dengan penagihan dan balikan yang menjadi satu paket terkait tugas dan hasil belajar pebelajar (mahasiswa) pada tiap pembelajaran berlangsung.

Dari segi pemanfaatan, hasil pengembangan telah dilengkapi dengan petunjuk pemanfaatan yang diperun-tukkan untuk mahasiswa maupun dosen untuk mempermudah menggunakan ha-sil pengembangan. Pedoman tersebut berupa beberapa petunjuk prosedural yang berisi langkah-langkah sebagai acuan dalam memanfaatkan program yang dikembangkan.

Mahasiswa dan dosen pengampu matakuliah memberikan respon yang sangat positif terhadap program pem-belajaran yang dikembangkan. Meski-pun bukan merupakan suatu hal yang baru, kehadiran program yang dikem-bangkan tersebut relatif menjadi hal yang menarik bagi mereka. Pengem-bangan tersebut sejalan dengan kebia-saan mereka yang sebagian besar telah terbiasa memanfaatkan teknologi dalam beberapa kegiatannya. Mahasiswa sang-at antusias belajar melalui akun edmodo masing-masing. Dari segi motivasi juga terdapat peningkatan belajar mahasiswa melalui program yang dikembangkan. Mahasiswa juga melakukan banyak persiapan sebelum menghadapi perkuliahan baik online maupun tatap muka, misalnya dengan cara merang-kum materi perkuliahan sebelum dan sesudah dilakukannya pertemuan di kelas.

Hasil dari pengembangan ini pun serupa dengan penelitian-penelitian sebelumnya yang pernah diadakan oleh beberapa peneliti sebagaimana dijelas-kan pada bagian sebelumnya. Dalam penelitian ini, fokus pengembangan terletak pada pengembangan pembela-jaran yang 
dipadukan dengan strategi self-regulated learning untuk mening-katkan kemandirian mahasiswa dalam belajar.

\section{SIMPULAN DAN SARAN}

Berdasarkan hasil penelitian dan pembahasan maka dapat disimpulkan bahwa pengembangan pembelajaran berbantuan web dapat meningkatkan kemampuan selfregulated learning ma-hasiswa. Terdapat peningkatan hasil belajar mahasiswa yang berarti telah memenuhi kriteria keberhasilan yang ditentukan. Peningkatan tersebut berdampak pada peningkatan kualitas pembelajaran dalam hal ini adalah sumber belajar bertambah dengan media belajar yang semakin variatif, sehingga dapat membantu membelajarkan mahasiswa.

Berdasarkan temuan tersebut maka dapat disarankan beberapa hal kepada berbagai pihak. Pertama, dosen hendaknya mengembangkan sumber be-lajar dalam berbagai betuk salah satunya berupa pembelajaran online yang dise-suaikan dengan kebutuhan dan karak-teristik pebelajar. Kedua, mahasiswa hendaknya membiasakan diri menggu-nakan berbagai sumber belajar, bukan hanya buku saja. Hal ini mengingat bahwa sumber belajar sudah semakin beragam dan akan berkembang terus sesuai dengan perkembangan teknologi informasi. Ketiga, peneliti berikutnya, pengembangan kemampuan self-regula-ted learning mahasiswa akan sangat mungkin berbeda karakteristiknya satu dengan yang lain. Oleh karena itu, dengan memanfaatkan perkembangan teknologi yang ada hendaknya dapat menggunakan berbagai media lain sehingga semakin menambah khasanah pengetahuan dalam usaha membantu belajar para mahasiswa. Selain itu Berdasarkan hasil pengembangan, maka diharapkan adanya penelitian-penelitian lain yang sejenis. Misalnya penelitian untuk mengetahui pengaruh dan efek-tivitas pembelajaran berbantuan web.

\section{DAFTAR RUJUKAN}

Peterson, C.L. and N. Bond. (2004). "Online Compared to Face-to Face Teacher Preparation for Learning Standards Based Plan-ning Skills, (Online), Journal of Research on Technology in Education, Vol. 36, No.4, ((https://scholar.google.co.id/scholar , diakses 5 Desember 2014).

Lee, Wiliiam W. \& Owens, Diana L. (2004). Multimedia-Based Ins-tructional Design: Computer Based Training, Web-Based Training, Distance Broadcast Training, PerformanceBased So-lutions. San Francisco: Pfeiffer, John Wiley \& Son, Inc. 